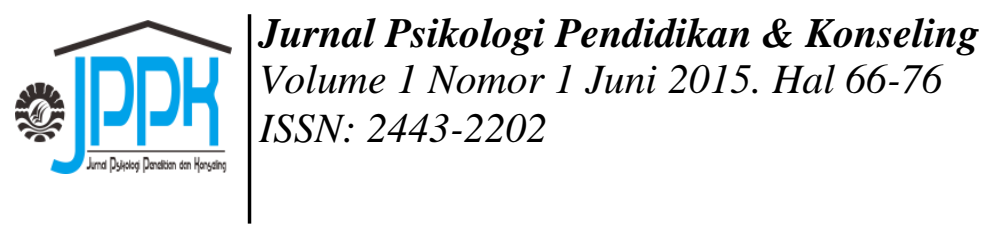

\title{
PERILAKU AGRESIF DAN PENANGANANNYA (STUDI KASUS PADA SISWA SMP NEGERI 8 MAKASSAR)
}

\author{
Salmiati \\ Bimbingan dan Konseling, STKIP Andi Matappa Pangkep \\ email: Salmi_unm86@yahoo.co.id
}

\begin{abstract}
This research aimed to (i) find out the form of the students' aggressive behaviour of SMPN 8 Makassar, (ii) find out the factors affecting the students' aggressive behaviour of SMPN 8 Makassar, (iii) find out the impact of the students' aggressive behavior of SMPN 8 Makassar, (iv) find out the treatment form of the students' aggressive behaviour of SMPN 8 Makassar. This research was case study and data collecting technique through interview, observation, and documentation. The data were analyzed by qualitative descriptive analysis. The result of this research showed that (i) the forms of aggressive student behaviour is a form of physical aggressive behaviour like hitting, slamming doors, banging the table, knocking over, throwing, hitting the table, pushing, and flicked the ear. The form of aggressive behaviour such as verbal threats, yelling, cursing, insulting, mocking, yelling, and calling a bad word. (ii) The factors affecting aggressive behavior are a) childhood experiences, b) will-treatment of parents, c) the support of parents and peers, d) the violent role models viewed from parents, peers and the habit of watching TV and playing games the scenes of violence, e) uncontrolled anger, f) frustration because of failure to achieve the goals, (iii) The impact of aggressive behaviour for both cases are low learning achievement and disharmony of social relationships with peers and (iv) The treatment form of aggressive behaviour through psychodrama technique.
\end{abstract}

Keyword: Aggressive behaviour, and psychodrama technique.

\begin{abstract}
Abstrak: Tujuan penelitian ini adalah (i) untuk mengetahui mengetahui bentuk perilaku agresif siswa di SMPN 8 Makassar. (ii) mengetahui faktor-faktor yang mempengaruhi perilaku agresif siswa di SMPN 8 Makassar. (iii) mengetahui dampak perilaku agresif bagi prestasi belajar dan hubungan dengan teman sebaya siswa di SMPN 8 Makassar. (iv) bentuk penanganan perilaku agresif siswa di SMPN 8 Makassar. Jenis penelitian ini adalah studi kasus. Pengumpulan data melalui wawancara, observasi dan dokumentasi. Data yang diperoleh dianalisis dengan analisis deskriptif kualitatif. Hasil penelitian; (i) bentuk perilaku agresif siswa adalah perilaku agresif fisik seperti memukul, membanting pintu, membanting meja, menyenggol, melempar, memukul meja, mendorong, dan menyentil telinga. Bentuk perilaku agresif verbal seperti mengancam, membentak, memaki, menghina, mengejek, berteriak dan memanggil dengan sebutan buruk. (ii) faktor yang memengaruhi perilaku agresif adalah (a) pengalaman masa kecil, (b) perlakuan buruk orangtua, (c) dukungan dari orangtua dan teman sebaya, (d) peran model kekerasan yang dilihat dari orangtua, teman sebaya, dan kebiasaan nonton TV dan main game yang beradegan kekerasan, (e) amarah yang tak terkontrol, (f) frustasi karena selalu gagal dalam mencapai tujuan. (iii) dampak perilaku agresif yaitu prestasi belajar rendah dan hubungan sosial dengan teman sebaya yang tidak baik dan (iv) bentuk penanganan perilaku agresif melalui teknik psikodrama.
\end{abstract}

Kata Kunci: Perilaku agresif, dan teknik psikodrama 


\section{PENDAHULUAN}

Keberhasilan remaja dalam menyelesaikan tugas perkembangan akan mengantarkannya ke dalam suatu kondisi penyesuaian sosial yang baik dalam keseluruhan kehidupannya. Namun, apabila remaja gagal dalam proses perkembangannya maka kemungkinan mereka akan melakukan tindakan-tindakan kriminal, kurang mampu bergaul dengan orang lain dan melakukan dominasi secara sewenang-wenang. Tindakan-tindakan yang dilakukan para remaja cenderung mengarah kepada perilaku agresif, baik secara individu maupun kelompok.

Penelitian yang telah dilakukan di Amerika Serikat menunjukkan bahwa terdapat sekitar 5-10 \% anak usia sekolah berperilaku agresif (Angraeni, 2011). Di Indonesia telah dilaporkan, baik melalui penelitian maupun pemberitaan surat kabar antara tahun 2002 2005 menunjukkan bahwa pada umumnya perilaku agresif terjadi di kalangan siswa, khususnya di kalangan siswa SMA (Kurniadarmi, 2005). Pemberitaan serupa yang telah ditayangkan dalam satu stasiun TV swasta menunjukkan bahwa perilaku agresif yang terjadi dikalangan siswa SMA pada kenyataannya juga terjadi dikalangan siswa SMP seperti fenomena yang terjadi di salah satu jalan ibu Kota Jakarta, terdapat dua kelompok remaja yang masih menggunakan seragam putih biru terlibat baku hantam, dan siswa-siswa tersebut adalah pelajar SMP yang sedang melakukan reaksi saling menyerang atau tawuran. Hal ini didukung pula hasil penelitian yang dikemukakan Thalib (2010) bahwa akhir-akhir ini perilaku agresif cenderung semakin meningkat terutama dikalangan siswa yang sering terlibat dalam berbagai bentuk kerusuhan, perkelahian, demonstrasi dan tindakan kekerasan lainnya yang menunjukkan semakin meningkatnya perilaku agresif siswa.

Fenomena perilaku agresif di Makassar juga menunjukkan hal serupa dengan yang terjadi di Indonesia pada umumnya. Di Makassar, khususnya remaja dari kalangan siswa SMA maupun siswa SMP juga sering melakukan perilaku agresif baik perilaku agresif fisik maupun agresif verbal, seperti hasil pemberitaan melalui tanyangan TV bahwa dari beberapa sekolah yang ada di Kota Makassar siswasiswinya sering terlibat dalam tindakan kekerasan berupa perilaku agresif.
Perilaku agresif yang umum dilakukan siswa di sekolah adalah tindakan perkelahian, melakukan konvoi di jalan raya sehingga mengganggu lalu lintas, membolos, dan melontarkan kata-kata yang tidak sopan seperti memaki, menghina, dan mengejek. Hasil penelitian yang dilakukan Harris (Thalib, 2010) juga menunjukkan bahwa pengalaman perilaku agresif ditunjukkan melalui berbagai bentuk perilaku seperti menyerang orang lain (memukul, menampar, menendang, menggigit) mengancam secara fisik atau verbal, melecehkan orang lain (mengejek, berteriak, berkata kasar), bersikap tidak sopan dan memaksa untuk memiliki bendabenda orang lain yang bukan miliknya.

Penyebab perilaku agresif yang dilakukan oleh siswa sangat kompleks, tetapi secara garis besar dapat dikelompokkan menjadi dua, yaitu penyebab internal dan eksternal seperti, amarah, frustasi, lingkungan, proses belajar model kekerasan, dan proses pendisiplinan yang keliru. Kedua faktor tersebut menyebabkan terhambatnya perkembangan aspek emosi dan sosial siswa yang bersangkutan. Terhambatnya perkembangan emosi dan perilaku sosial di antaranya diwujudkan dalam bentuk perilaku agresif. Hal ini berdampak pula pada perkembangan emosi dan perilaku siswa di sekolah. Selain itu, perilaku agresif juga dapat memengaruhi prestasi akademis, interaksi sosial mereka dengan teman sebaya dan guru. Sebagaimana Kauffman (Setiawan, 2012) dalam hasil risetnya menjelaskan bahwa anak yang agresif umumnya memiliki prestasi akademik yang rendah untuk usia mereka, mayoritas anak agresif memiliki kesulitan akademis, memiliki kekurangan dalam keterampilan sosial yang mempengaruhi kemampuan untuk kerjasama dengan guru, fungsi di dalam kelas, dan bergaul dengan siswa lain.

Fenomena di lapangan menunjukkan bahwa perilaku agresif yang di lakukan kasus tidak tergantung pada latar belakang sekolah tempat kasus menuntut ilmu pendidikan. Hal ini dibuktikan dari hasil studi pendahuluan yang diperoleh dari wawancara dengan guru di SMP Negeri 8 Makassar bahwa sekolah yang beralokasikan di Jalan Batua Raya No. 1 merupakan salah satu sekolah favorit dan sangat banyak diminati oleh para siswa yang hendak melanjutkan pendidikan pada tingkat sekolah menengah pertama. Seleksi untuk masuk di sekolah tersebut juga termasuk sangat ketat 
dengan melalui beberapa tahapan seleksi, seperti tes tertulis, tes wawancara, psikotes dan tes baca tulis Al-Qur'an. Namun, hal itu tidak bisa memberikan jaminan, karena pada kenyataannya masih terdapat siswa yang menunjukkan penyimpangan perilaku karena disebabkan oleh beberapa faktor, baik faktor eksternal maupun faktor internal. Perilaku menyimpang yang dimaksudkan salah satunya adalah perilaku agresif seperti yang dilakukan oleh kedua kasus.

Hasil studi pendahuluan selanjutnya di lokasi penelitian SMP Negeri 8 Makassar diperoleh informasi dari guru pembimbing, guru mata pelajaran dan wali kelas bahwa siswa mengalami kecenderungan berperilaku agresif. Untuk mengetahui bentuk-bentuk perilaku agresif yang terjadi, maka ditindak lanjuti dengan observasi. Hasil analisisnya menunjukkan bahwa tindakan agresif yang cenderung dilakukan siswa berupa memukul, mengancam, mengejek, menantang, memaksa, berkata kasar, bersikap tidak sopan yang disertai dengan tindakan memukul benda-benda yang ada di dekatnya seperti membanting pintu ruangan dan memukul meja. Tindakan yang dilakukan kedua siswa tersebut tergolong perilaku agresif emosional yang unik karena perilaku agresif yang dilakukan didorong untuk memperoleh kesenangan ketika menyakiti orang lain. Hal ini disebabkan oleh ketidakmampuannya untuk mengendalikan atau mengontrol emosi yang ditunjukkan dengan mudah marah jika diganggu, mudah merasa mendapat ancaman dan serangan, sangat sensitif atau mudah tersinggung terhadap ejekan atau hinaan dan mudah menyerang atau menyakiti orang lain.

Berdasarkan fenomena tersebut di atas, maka guru BK melakukan berbagai bentuk penanganan, baik dalam bentuk konseling maupun dalam bentuk bimbingan kelompok untuk membantu siswa atau anak didiknya dalam mengatasi perilaku agresif yang cenderung dilakukan, khususnya bagi kedua kasus yang menjadi subjek penelitian dengan memberikan penanganan dalam bentuk konseling kelompok melalui teknik relaksasi dan bimbingan kelompok melalui pemberian informasi mengenai perilaku agresif secara klasikal. Penanganan yang dilakukan mampu membantu siswa dalam menangani perilakunya. Namun, berdasarkan kajian literatur dan melihat latar belakang permasalahan yang dialami kedua kasus, maka masih dibutuhkan bentuk penanganan yang lebih tepat untuk membantu siswa dalam menangani perilaku agresif yang dilakukan yaitu melalui teknik psikodrama. Teknik psikodrama dipandang cocok untuk membantu siswa dalam menangani perilaku agresif. Hal ini didukung oleh pernyataan yang dikemukakan Semium (2006) bahwa psikodrama merupakan salah satu teknik dalam bimbingan kelompok yang dapat digunakan konselor dalam menangani masalah-masalah emosional, dan masalah emosional yang dimaksudkan salah satunya adalah perilaku agresif.

Teknik psikodrama dilaksanakan dalam bentuk role playing, dan hal ini sesuai dengan pendapat Bennet (Romlah, 2001) bahwa psikodrama adalah bagian dari permainan peranan (role playing). Permainan peran yang ditampilkan siswa melalui teknik psikodrama diupayakan mampu membantu siswa untuk mengurangi kecenderungan perilaku agresif di sekolah. Melalui teknik psikodrama siswa akan memerankan suatu peran yang akan menampilkan atau memperagakan suatu penyelesaian masalah yang tidak menggunakan perilaku agresif. Hal ini di dukung oleh hasil penelitian yang dilakukan oleh Setiawan (2012) yang menyatakan bahwa salah satu upaya yang dapat dilakukan untuk mengendalikan perilaku agresif pada anak yaitu dengan strategi memperagakan/pelatihan, karena ketika anak melihat suatu contoh dan memilih solusi yang tidak agresif terhadap suatu konflik atau dengan memberikan pelatihan untuk menggunakan metode-metode yang tidak agresif tentang pemecahan masalah, memungkinkan mereka untuk menetapkan sendiri solusi yang tepat untuk permasalahan yang mereka alami. Selain itu, psikodrama merupakan suatu bentuk terapi kelompok, dimana anggota kelompok didorong untuk memainkan suatu peran emosional di depan para penonton tanpa dia dilatih sebelumnya dengan tujuan untuk membantu anggota kelompok atau pasien mampu mengatasi masalah-masalah pribadi dengan menggunakan permainan drama, peran, atau terapi tindakan yang akhirnya akan mengungkapkan perasaanperasaan tentang konflik, kemarahan, agresi, perasaan bersalah dan kesedihan, Moreno (Semium, 2006).

Berdasarkan latar belakang tersebut di atas, fokus masalah dalam penelitian ini adalah: 1) Bagaimanakah bentuk-bentuk perilaku agresif siswa di SMP Negeri 8 Makassar?, 2) Faktor- 
faktor apakah yang mempengaruhi perilaku agresif siswa di SMP Negeri 8 Makassar?, 3) Bagaimanakah dampak perilaku agresif terhadap prestasi belajar dan hubungan dengan teman sebaya siswa di SMP Negeri 8 Makassar?, 4) Bagaimanakah bentuk penanganan perilaku agresif siswa di SMP Negeri 8 Makassar?

Mengacu pada fokus masalah penelitian di atas, penelitian ini bertujuan: 1) Untuk mengetahui bentuk-bentuk perilaku agresif siswa di SMP Negeri 8 Makassar., 2) Untuk mengetahui faktor-faktor yang mempengaruhi perilaku agresif siswa di SMP Negeri 8 Makassar. 3) Untuk mengetahui dampak perilaku agresif bagi prestasi belajar dan hubungan dengan teman sebaya siswa di SMP Negeri 8 Makassar. 4) Untuk mengatahui bentuk penanganan perilaku agresif siswa di SMP Negeri 8 Makassar.

\section{METODE}

Pendekatan yang digunakan dalam penelitian ini adalah pendekatan kualitatif. Penelitian ini menggunakan jenis studi kasus, yaitu suatu penelitian yang menghasilkan data deskriptif yang bisa berupa kata-kata tertulis atau lisan dari orang-orang dan tingkah laku yang diamati. Pendekatan ini didasarkan atas pertimbangan bahwa pendekatan ini akan menyajikan secara langsung dan mengkaji secara mendalam masalah-masalah yang menjadi fokus penelitian (Moleong, 1996).

Penelitian dilaksanakan selama dua bulan mulai tanggal 5 Mei 2012 sampai dengan 8 Juli 2012 terhadap kedua subjek yang berperilaku agresif di sekolah yang berlokasi di SMP Negeri 8 Makassar Jl. Batua Raya Sulawesi Selatan.

Deskripsi fokus penelitian atau definisi operasional dalam penelitian ini adalah: 1) Perilaku agresif adalah tindakan kekerasan yang dilakukan dengan tujuan untuk menyakiti orang lain atau merusak suatu benda, dalam bentuk agresif verbal dan fisik. Perilaku agresif verbal yang dilakukan siswa berupa mengejek, membentak, menghina, memaki dan mengancam. Sedangkan agresif fisik yang dilakukan siswa berupa memukul, menendang, mengigit, mencubit, melempar, mendorong dan melukai orang lain. 2) Faktor-faktor perilaku agresif adalah kondisi-kondisi yang menyebabkan siswa berperilaku agresif, baik agresif verbal maupun agresif fisik. Seperti pengalaman masa kecil, hadiah berupa dukungan dari orangtua dan teman sebaya, peran model yang dilihat dari orangtua dan teman, perlakuan buruk orangtua, pendisiplinan yang keliru, ketidakjelasan hukuman yang diberikan, amarah dan frustasi. 3) Dampak perilaku agresif adalah akibat yang diperoleh dan dialami siswa dari perilaku atau tindakan kekerasan yang telah dilakukan. Dampak ini bisa berpengaruh pada prestasi belajar dan hubungan dengan teman sebaya. 4) Teknik psikodrama adalah bentuk penanganan perilaku agresif yang diberikan kepada kedua kasus dengan tujuan untuk membantu kasus mengubah perilaku agresif menjadi perilaku yang tidak agresif.

Instrument dalam penelitian ini dibagi atas dua bagian yaitu: 1) Teknik pengumpulan data. Pengumpulan data digunakan untuk memperoleh data dan informasi tentang bentuk-bentuk perilaku agresif yang dilakukan siswa, faktorfaktor yang mempengaruhi siswa berperilaku agresif, dampak perilaku agresif terhadap prestasi belajar dan hubungan dengan teman sebaya dan gambaran bentuk penanganan perilaku agresif siswa, maka teknik pengumpulan data yang digunakan adalah:

Observasi merupakan proses pengamatan terhadap subjek penelitian pada realitas kehidupan yang alamiah, yaitu kehidupan yang dijalani subjek sehari-hari. Becker \& dkk (Mulyono, 2003). Observasi digunakan untuk memperoleh gambaran data tentang bentukbentuk perilaku agresif siswa dan memperoleh gambaran pelaksanaan psikodrama dalam menangani perilaku agresif siswa.

Wawancara. Kegiatan wawancara merupakan teknik utama dalam pengumpulan data guna memperoleh data atau informasi dari informan penelitian yang lebih detail tentang perilaku agresif subjek penelitian dan mengetahui tingkat perubahan yang terjadi pada siswa setelah diberikan penanganan melalui teknik psikodrama. Wawancara dilakukan dengan menggunakan pedoman wawancara. Pelaksanaan wawancara disesuaikan dengan keadaan/kondisi responden agar dapat memberikan informasi yang sebanyakbanyaknya sesuai dengan tujuan penelitian.

Sosiometri.Sosiometri merupakan metode yang digunakan untuk memperoleh data tentang hubungan sosial siswa dengan teman sebaya. Sosiometri diberikan kepada kedua subjek 
masing-masing di kelas VII $\mathrm{G}$ dan kelas VII H bersama teman-temannya disela-sela pelajaran kosong yaitu dilaksanakan pada tanggal 16 Juni 2012. Hasil yang diperoleh melalui sosiometri memberikan gambaran yang jelas bahwa perilaku kedua kasus tidak disenangi oleh temantemannya. Hasilnya dikelola dan dikelompokan menjadi dua bagian yaitu teman yang paling disenangi dan paling tidak disenangi untuk diajak bergaul.

Dokumentasi. Data dokumentasi yang diperoleh oleh peneliti adalah data hasil prestasi bejalar kedua kasus yaitu foto copy raport pada kelas VII semester 1 dan 2 untuk membandingkan data yang diperoleh dari hasil wawancara dengan keadaan diri kasus yang sebenarnya. Hal ini untuk memperkuat informasi dan data yang diperoleh tentang dampak atau akibat yang dialami oleh siswa selama berperilaku agresif. Dokumentasi dalam penelitian ini digunakan untuk memperoleh data yang menurut peneliti masih dibutuhkan dan relevan dengan fokus penelitian sehingga dapat memberikan bahan deskriptif.

Bahan perlakuan. Bahan perlakuan yang dimaksudkan dalam penelitian ini adalah bentuk penanganan yang diberikan kepada kedua subjek penelitian dengan tujuan untuk membantu subjek dalam menangani perilaku agresif yaitu melalui teknik psikodrama. Dalam pelaksanaan psikodrama, ada beberapa hal yang harus dipersiapkan: 1) Panduan pelaksanaan psikodrama. Panduan pelaksanaan psikodrama mencakup beberapa hal yang harus diperhatikan seperti tujuan pelaksanaan, persiapan, pemberian inforamasi, pembetukan kelompok latihan psikodrama, pemberian latihan psikodrama dengan menggunakan tema psikodrama, pemberian pekerjaan rumah, pemberian evaluasi diri setelah pelaksanaan psikodrama, diskusi dan berbagi pendapat dan perasaan, dan terminasi., 2) Bahan informasi. Bahan informasi yang telah disiapkan diberikan kepada siswa yang menjadi subjek penelitian dengan tujuan untuk membantu subjek penelitian dalam memahami maksud dan tujuan dari pemberian teknik psikodrama. informasi yang diberikan berupa keteranganketerangan mengenai konsep dasar psikodrama, tujuan psikodrama, prosedur pelaksanaan psikodrama, dan komponen-komponen dalam pelaksanaan psikodrama., 3) Panduan pembentukan kelompok psikodrama. Panduan pembentukan kelompok psikodrama digunakan untuk membantu anggota kelompok dalam menciptakan suasana kelompok yang efektif dan dinamis agar setiap anggota kelompok memiliki rasa tanggung jawab untuk dapat menjalin hubungan baik, berinteraksi, dan bekerjasama satu sama lain dalam kelompok, dapat mengemukakan pendapatnya mengenai apa yang dirasakan berkaitan dengan masalah yang dialami secara bebas tanpa rasa malu dan segan, dapat mengemukakan harapan-harapan dan hambatan-hambatan dalam mengikuti psikodrama. 4) Skenario psikodrama. Skenario psikodrama digunakan untuk membantu siswa dalam memberikan gambaran awal mengenai permasalahan yang dialaminya, sehingga melalui skenario psikodrama siswa merasa terpancing untuk memainkan adegan yang sesuai dengan kehidupan nyata yang masing-masing mereka alami. 5) Pedoman observasi. Pedoman observasi digunakan untuk melihat aktivitas-aktivitas anggota kelompok selama proses pelaksanaan psikodrama berlangsung. Data hasil observasi akan mendukung hasil yang diperoleh dari pelaksanaan psikodrama untuk membantu kasus dalam menangani perilaku agresif. 6) Lembar tugas untuk psikodrama. Lembar tugas untuk psikodrama diberikan kepada anggota kelompok untuk melakukan penilaian terhadap dirinya sendiri sekaligus untuk menentukan upayauapaya penanganan perilaku agresif melalui teknik psikodrama., 7) Lembar evaluasi diri dalam psikodrama. Lembar evaluasi diri dalam psikodrama digunakan oleh anggota kelompok untuk menuliskan berbagai kesulitan-kesulitan yang mereka hadapi selama proses psikodrama berlangsung dan untuk mengetahui upaya yang harus mereka lakukan untuk mengatasi kesulitan dalam melakukan permainan peran melalui teknik psikodrama sekaligus untuk mengungkapkan pesan dan kesan serta harapannya terhadap pelaksanaan psikodrama.

Subjek utama dalam penelitian sebanyak dua orang siswa yang berinisial FT dan AR yang mengalami masalah perilaku agresif dan berada di kelas VII G dan VII H.

Kedua subjek dipilih secara selektif sebagai subjek dalam peneltian ini, karena keduanya memiliki masalah yang sama yaitu berperilaku agresif. Selain itu, keduanya juga bersedia memberikan informasi yang dibutuhkan peneliti selama penelitian ini berlangsung.

Selain kedua subjek utama tersebut, peneliti memilih beberapa informan lainnya 
sebagai sumber data sekunder seperti orangtua, guru mata pelajaran, wali kelas, guru pembimbing, ketua kelas, dan teman/sahabat subjek. Informan ini dipilih dengan alasan bahwa merekalah yang paling dekat dengan kasus sehingga untuk menguatkan imformasi dan fakta yang diperoleh akan lebih mudah diperolah melalui informan yang mengetahui keadaan dan kondisi subyek sehari-hari di sekolah.

Sumber data dalam penelitian ini adalah kata-kata dan tindakan subjek, sumber tertulis dan data tambahan. Jenis data yang dikumpulkan adalah (1) data dan informasi tentang bentukbentuk perilaku agresif siswa, (2) data dan informasi tentang faktor-faktor yang mempengeruhi perilaku agresif, (3) data dan informasi tentang dampak perilaku agresif terhadap prestasi belajar dan hubungan teman sebaya dan (4) data tentang bentuk penanganan perilaku agresif siswa.

Analisis data dalam penelitian kualitatif dilakukan sejak sebelum memasuki lapangan, selama di lapangan, dan setelah selesai di lapangan (Shank, 2006: 152). 1) Analisis sebelum di lapangan, yakni peneliti melakukan analisis terhadap data hasil studi pendahuluan atau data sekunder yang akan digunakan untuk menentukan fokus penelitian. Dalam hal ini peneliti melakukan observasi awal sebelum melakukan penelitian dengan melakukan wawancara terhadap guru BK di SMP Negeri 8 Makassar. 2) Analisis selama di lapangan Model Miles dan Huberman terdiri dari tiga langkah meliputi reduksi data, penyajian data dan penarikan kesimpulan.

Reduksi data, peneliti memilih dan menyederhanakan data hasil observasi dan hasil wawancara ke dalam tiga pokok umum yaitu data tentang gambaran perilaku agresif siswa, faktor-faktor yang mempengaruhi perilaku agresif, dampak perilaku agresif terhadap prestasi belajar siswa dan hubungan dengan teman sebaya serta penanganan perilaku agresif melalui teknik psikodrama. Untuk ini, peneliti melakukan beberapa langkah memilih, menyederhanakan data dan informasi tersebut malalui: 1) Mengorganisasikan data, peneliti membuat catatan-catatan lapangan dalam bentuk tertulis tentang bentuk-bentuk perilaku yang ditampilkan subjek yang berperilaku agresif, faktor-faktor yang mempengaruhi perilaku agresif, dampak perilaku agresif terhadap prestasi belajar dan hubungan dengan teman sebaya serta penanganan perilaku agresif melalui teknik psikodrama. Peneliti membuat dalam bentuk tulisan yang dapat dipahami., 2) Mengelompokkan, mengkategorikan dan mengkode data. Upaya peneliti mengelompokkan data dan informasi adalah dengan cara menyusun pernyataan-pernyataan hasil wawancara secara kronologis mulai dari penyataan-pernyataan yang berkaitan dengan bentuk-bentuk perilaku agresif, pernyataan-pernyataan yang berkaitan dengan faktor-faktor yang mempengaruhi perilaku agresif, dan pernyataan-pernyataan yang berkaitan dengan dampak perilaku agresif terhadap prestasi belajar dan hubungan dengan teman sebaya

Selanjutnya untuk memudahkan dalam menganalisis data dan informasi yang telah dikategorikan seperti di atas, pada catatan lapangan hasil wawancara tidak lupa peneliti membuat kode seperti berikut:

Tabel 3.2. Pengkodean hasil wawancara

\begin{tabular}{clc}
\hline No & Fokus Penelitian & Kode \\
\hline 1 & Bentuk-bentuk perilaku agresif & $\mathrm{A}$ \\
& 1.1 agresif fisik & $\mathrm{a} .1$ \\
& 1.2 agresif verbal & $\mathrm{a} .2$ \\
\hline 2 & Faktor-faktor yang mempengeruhi perilaku agresif & $\mathrm{B}$ \\
& 2.1 pengalaman masa kecil & $\mathrm{b} .1$ \\
& 2.2 pengaruh langsung & $\mathrm{b} .2$ \\
& 2.3 pengaruh tak langsung & $\mathrm{b} .3$ \\
& 2.4 frustasi & $\mathrm{b} .4$ \\
& 2.5 amarah & $\mathrm{b} .5$ \\
\hline 3 & Dampak perilaku agresif & $\mathrm{c}$ \\
& 3.1 kegagalan akademik & $\mathrm{c} .1$ \\
& 3.2 hubungan sosial & $\mathrm{c} .2$ \\
\hline
\end{tabular}


Penyajian data, data dan informasi yang telah peneliti pilih dan sederhanakan kemudian disajikan dalam bentuk catatan-catatan lapangan hasil observasi dan catatan-catatan hasil

Wawancara. Peneliti menyajikan data hasil pengamatan dalam bentuk uraian singkat yang disimpulkan berdasarkan akumulasi dari perilaku yang tampak pada setiap kali observasi. Hasil wawancara dirangkum dan dibuat kesimpulan setiap kali wawancara dilakukan terhadap sumber data. Setelah itu data yang telah diperolah dari hasil pengamatan dan hasil wawancara disajikan apa adanya dalam bentuk deskripsi atau uraian singkat.

Penarikan kesimpulan, tahap selanjutnya yang peneliti lakukan adalah penarikan kesimpulan, yaitu data dan informasi yang telah dibuat dalam bentuk tertulis, kemudian peneliti membaca berulang-ulang untuk kemudian disimpulkan dan diberi interpretasi makna dari fakta yang ada, yaitu perilaku-perilaku agresif yang ditampilkan subjek, gambaran faktorfaktor yang mempengaruhi perilaku agresif, dampak perilaku agresif terhadap prestasi belajar dan hubungan dengan teman sebaya serta gambaran bentuk penanganan perilaku agresif. Langkah verifikasi yang dilakukan oleh peneliti dengan mengkonfirmasikan kesimpulan hasil pengamatan dan hasil wawancara selama penelitian berlangsung sehingga validitasnya lebih terjamin.

Pemahaman dan penghayatan terhadap konteks yang diteliti, peneliti melakukan penelitian dengan tekun dan mencatat setiap hasil wawancara dan hasil pengamatan. Untuk mengujikan keabsahan data yang diperoleh, peneliti melakukan triangulasi metode dan triangulasi sumber. Triangulasi metode dilakukan dengan cara membandingkan penemuan hasil penelitian yang diperoleh dengan berdasarkan wawancara dengan data yang diperoleh melalui pengamatan pada setiap kesempatan pertemuan antara peneliti dengan subjek. Pengamatan yang dilakukan pada subjek dilakukan selama mungkin di mana subjek tidak menyadari bahwa peneliti sedang melakukan pengamatan pada diri subjek. Apabila tidak terjadi ketidaksesuaian antara hasil pengamatan dengan hasil wawancara, maka peneliti mencoba mencari data melalui wawancara dan pengamatan berikutnya.

Triangulasi sumber dilakukan dengan cara melakukan wawancara dengan beberapa informan yang memiliki kedekatan dan mengetahui keadaan subjek yang diteliti yaitu orangtua, guru mata pelajaran, guru pembimbingan, wali kelas, ketua kelas, dan teman/sebaya subjek. Hasil wawancara dengan subjek untuk melihat apakah data tersebut saling mendukung atau saling bertolak belakang. Hal ini untuk memastikan kebenaran informasi hasil wawancara dan pengamatan pada subjek. Jika data dari sumber penelitian ini sesuai dengan data yang diperoleh dari subjek penelitian, maka data tersebut memiliki tingkat kepercayaan, sehingga tingkat kebenaran kesimpulan akhir penelitian dapat dipertanggungjawabkan.

\section{HASIL DAN PEMBAHASAN}

Bentuk perilaku agresif yang diperoleh melalui hasil wawancara serta hasil pengamatan terbagi atas dua bentuk yaitu perilaku agresif bentuk fisik dan verbal. Bentuk agresif fisik seperti memukul, membanting meja, membanting pintu, mendorong, melempar menggunakan remot TV, memecahkan bendabenda dan mencolek-colek temannya, dan menyentil telinga teman. Sedangkan perilaku agresif dalam bentuk verbal seperti mengejek, menghina memanggil dengan sebutan buruk, mengancam, membentak-bentak, memaki, dan berteriak.

Perilaku agresif yang terjadi dipengaruhi beberapa faktor seperti pengalaman masa kecilnya, perlakuan buruk orangtua, dukungan dari orangtua dan teman sebaya terhadap perilakunya, peran model yang sering dilihat baik dari orangtuanya ataupun teman bergaulnya dalam bentuk tindakan langsung ataupun dalam bentuk cerita, keseringannya menonton film serta main game yang menunjukkan adegan kekerasan, seringnya mengalami kegagalan dalam mencapai tujuannya dan ketidakmampuannya dalam mengendalikan perasaan amarahanya, penerapan kedisiplinan yang keliru, hadiah yang diperoleh dari orangtua dalam bentuk pujian karena berani memukul temannya serta seringnya subjek mengalami perlakuan yang tidak baik serta mengalami kegagalan dalam mencapai tujuan yang menyebabkan subjek merasa frustasi kemudian melampiaskannya dalam bentuk perilaku agresif.

Perilaku agresif tentunya menimbulkan dampak bagi keduanya, baik yang berkaitan dengan proses belajarnya maupun yang berkaitan dengan hubungan sosialnya dengan teman-temannya di di sekolah, dampak yang 
berkaitan dengan proses belajarnya adalah subjek sulit berkonsentrasi dalam belajar, selalu gelisah dalam mengikuti proses pembelajaran, sering mengganggu teman-temannya yang serius belajar, selalu gelisah, tidak tenang, dan sering tidak mengerjakan tugas yang diberikan oleh guru. Hal ini tentunya mempengeruhi pecapainya prestasi belajarnya di sekolah. Sedangkan dampak yang berkaitan dengan hubungan sosialnya adalah subjek cenderung dijauhi oleh teman-temannya karena takut disakiti/dipukuli dan cenderung tidak disenangi oleh teman-temannya karena perilakunya yang sering mengganggu teman-temannya dalam bentuk perilaku agresif.

Bentuk penanganan perilaku agrasif yang dapat dilakukan adalah penanganan melalui konseling kelompok dengan menggunakan pendekatan behavioral melalui teknik relaksasi, penanganan melalui bimbingan kelompok dengan teknik pemberian informasi terkait perilaku agresif. Serta penanganan melalui psikodrama.

Bentuk perilaku agresif yang cenderung dilakukan kedua sebjek penelitian cenderung mengarah pada dua bentuk perilaku agresif yaitu agresif fisik dan agresif verbal. Sebagaimana yang dikemukakan oleh Moore dan Fine (Koeswara, 1988) bahwa perilaku agresif verbal yaitu agresif yang dilakukan dengan cara menyerang secara verbal seperti mengejek, membentak, menghina, dan lain-lainnya. Agresif fisik yaitu agresif yang dilakukan dengan menggunakan kemampuan fisik seperti menendang, menggigit, mencubit, melempar dan lain-lainnya.

Berkaitan perilaku agresif dalam bentuk fisik misalnya membanting meja, membanting pintu, melempar dengan menggunakan remot TV dan memecahkan benda-benda. Perilaku agresif tersebut digolongkan pada perilaku agresif menyerang dengan benda. Sebagaimana Paterson (Malik, 2005) menggolongkan salah satu perilaku agresif yaitu menyerang dengan benda, contohnya: membanting buku, membanting pintu, atau memukul-mukul tembok.

Faktor-faktor yang mempengaruhi perilaku agresif. Ada beberapa faktor yang menyebabkan kasus untuk melakukan perilaku agresif, salah satunya adalah pengalaman masa kecil. Hal ini didukung dengan penelitian yang dilakukan oleh McCord dan McCord mendapati bahwa perilaku orangtua terhadap anak-anaknya jelas mempengaruhi kemungkinan anak-anak itu menjadi apa yang diistilahkan "agresive reactive emotional" dalam pergaulan mereka dengan teman sebaya dan gurunya. Selain itu, orangtua mereka juga sering memperingatkan untuk melakukan perlawanan kalau ada yang berani mengganggunya. Hal ini sesuai dengan hasil pengkajian yang dilakukan oleh McCord (Berkowitz, 2003: 212) yang mencatat hubungan antara cara orangtua mendidik anak terhadap kejahatan yang dilakukan anak mereka tiga puluh tahun kemudian, dan hasilnya menunjukkan bahwa pengalaman keluarga sewaktu kecil bisa membantu membentuk jalan hidup mereka setelah dewasa dan bahkan bisa mempengaruhi kemungkinan mereka menjadi pelanggar hukum.

Faktor lain yang menyebabkan seseorang berperilaku agresif, ada yang bersifat langsung dan ada yang tak langsung. faktor yang dimaksudkan adalah adanya pemberian hadiah berupa dukungan dari teman sebaya dan orangtua ketika melakukan tindakan agresif. Hal ini sesuai dengan yang dikemukakan oleh Berkowitz (2003: 212) bahwa hadiah atau imbalan bisa mempengaruhi perilaku dengan dua cara yang agak berbeda, hadiah bisa berlaku sebagai insentif yang mendorong suatu tindakan atau bisa merupakan penguat yang berfungsi mempertahankan perilaku jenis tertentu. Hadiah yang dimaksudkan dapat berupa : 1) dukungan dari orangtua seperti mendorong anaknya untuk berkelahi dan memberikan balasan ketika digertak orang lain 2) hadiah dari teman-teman seperti temannya berperan sebagai model dan memberikan hadiah berupa penerimaan atau bahkan dukungan terbuka jika mereka bertindak dengan cara yang dianggap pas 3) kelompok dan geng memberikan pengaruh terhadap perilaku agresif anak seperti mencari teman yang bisa menghargainya, berteman dengan anak-anak yang sering terlibat dalam perkelahian, serta membentuk geng untuk memberikan rasa aman, status dan harga diri.

Pengaruh langsung lainnya yang bisa menyebabkan seseorang dalam melakukan perilaku agresif yaitu adanya perlakuan buruk dari orangtua, penerapan kesiplinan yang keliru dan ketidakjelasan hukuman yang diberikan oleh orangtua. Menurut Olweus (Berkowitz, 2003: 229) bahwa perlakuan orangtua yang keras dan suka menghukum cenderung menghasilkan anak-anak yang sangat agresif dan antisosial. Selain itu Berkowitz (2003: 228) mengemukakan bahwa penolakan orangtua 
dapat berupa kurangnya kasih sayang yang diberikan oleh orangtua terhadap anaknya cenderung menyebabkan anak berperilaku agresif.

Ketidakjelasan hukuman yang diberikan juga menjadi salah satu pemicu terjadinya perilaku agresif. Padahal seharusnya sebagai orangtua harus memberikan penjelasan kepada anak agar anak dapat memahami akibat ditimbulkan oleh perilakunya dan mampu mengarahkan diri kearah yang lebih baik. Seperti yang dikemukakan oleh Berkowitz (2003: 233) bahwa hukuman yang diberikan orangtua harus dijelaskan secara baik agar anakanak bisa mematuhi prinsip tersebut dengan baik.

Pengaruh tak langsung yang menyebabkan terjadinya perilaku agresif adalah seringnya mereka menyaksikan orang-orang yang ada di sekilingnya melakukan tindakan kekerasan, misalnya seringnya mereka melihat orangtuanya berselisih paham, melihat temanteman bergaulnya melakukan tindakan kekerasan, serta sering main game dan menyaksikan tanyangan TV yang beradegan kekerasan. Menurut Bandura (Berkowitz, 2003: 245) disebut sebagai modeling dan mendifinisikannya sebagai pengaruh yang timbul ketika orang melihat orang lain (model) bertindak dengan cara tertentu dan kemudian meniru perilaku orang. Model yang dimaksudkan yaitu: (1) teman dan orangtua sebagai model perilaku menyimpang, (2) kondisi yang mempengaruhi pengaruh model seperti terdorong untuk bertindak dengan cara yang sama dan kekuasaan model atas anak yang memperhatikannya.

Amarah juga mimiliki pengaruh yang besar terhadap terjadinya perilaku agresif. Sebagaimana yang dikemukakan oleh Novaco (Berkowitz, 2003: 75) bahwa amarah sebagai suatu reaksi tekanan perasaan yang dasar cenderung membuat orang menjadi marah dan terdorong menjadi agresif jika harus menghadapi keadaan yang mengganggu. Misalnya orang yang secara terbuka berperilaku agresif baik secara verbal maupun fisik karena mereka merasa terhina dan harga dirinya tersinggung.

Pengaruh lainnya yang menyebabkan seseorang berperilaku agresif adalah frustasi. Frustasi menurut Koeswara (1998) merupakan suatu situasi yang menghambat individu dalam usaha mencapai tujuan tertentu yang diinginkan, dari frustasi maka akan timbul perasaanperasaan agresif.

Dampak perilaku agresif, Dampak perilaku agresif tidak hanya mempengaruhi fungsi anak dalam perkembangan emosi dan perilaku, tetapi hal tersebut juga mempengaruhi prestasi akademis, interaksi sosial mereka dengan teman sebaya dan guru. Hal ini di dukung oleh pernyataan Petterson (Berkowitz, 2003: 240) yang mengemukakan bahwa kemungkinan anak antisosial akan ditolak oleh teman-temannya yang lebih normal, dan sebenarnya agresivitas anak seperti itu lebih banyak merupakan akibat dari penolakan sosial.

Bentuk penanganan perilaku agresif. Perilaku agresif yang dilakukan kedua kasus tujuan utamanya hanyalah untuk mendapatkan kesenangan dan hanya merupakan salah satu bentuk pelampiasaan emosional. Untuk itu, melihat dari faktor-faktor yang menyebabkan kasus FT dan AR berperilaku agresif, maka salah satu upaya penanganan yang dapat diterapkan untuk membantu kasus keluar dari masalahnya adalah melalui teknik psikodrama. Hal ini sesuai yang dikemukakan oleh Semium (2000: 564) bahwa psikodrama dapat digunakan oleh konselor untuk membantu memecahkan masalah-masalah klien yang bersifat psikologi. Psikodrama juga dapat digunakan dalam terapi perkawinan, dalam terapi anak-anak, penyalahgunaan-penyalahgunaan obat bius dan alkohol, orang-orang yang mengalami masalahmasalah emosional, di lingkungan penjara, untuk melatih para psikiater di rumah sakit, untuk melatih orang-orang yang cacat, diperusahaan dan industry, dan dalam pendidikan serta dalam mengambil keputusan. Masalah emosional yang dimaksudkan salah satunya adalah perilaku agresif.

\section{SIMPULAN DAN SARAN}

Hasil penelitian ini memberikan gambaran bahwa secara umum perilaku agresif terbagai atas dua bentuk yaitu agresif fisik dan agresif verbal. Agresif seperti memukul, mendorong, membanting pintu, membanting meja, memecahkan barang-barang yang ada disekelilingnya, memukul meja, menyenggol menyentil telinga temannya dan melempar sedangkan agresif dalam bentuk verbal seperti mengejek, menghina, memaki, memanggil dengan sebutan buruk, membentak dan mengancam. 
Secara umum faktor yang menyebabkan perilaku agresif seperti: (a) pengalaman masa kecil, (b) Perlakuan buruk orangtua, (c) dukungan dari orangtua dan teman sebaya, (d) pendisipilinan yang keliru, (e) ketidakjelasan hukuman yang diberikan, (f) peran model dari orangtua, teman sebaya dan kebiasaan menonton serta main game yang beradegan kekerasan, $(\mathrm{g})$ amarah yang tidak terkontrol, dan (h) frustasi yang dinampakkan pada saat menginginkan sesuatu dan tak tercapai pasti pelampiasannya dalam bentuk perilaku agresif. Namun secara khusus yang membedakan faktor penyebab perilaku agresif kedua kasus tergantung dari kondisi psikologis, lingkungan keluarga dan lingkungan tempat tinggal kedua kasus.

Perilaku agresif berdampak terhadap prestasi belajar seperti prestasi belajar rendah karena kedua kasus memiliki kebiasaan tidak menyelesaikan tugas-tugas yang diberikan guru, sulit berkonsentrasi, dan tidak bisa duduk dengan tenang pada saat proses belajar mengajar berlangsung di dalam kelas. Dampaknya terhadap hubungan sosial dengan teman sebaya, yaitu dijauhi oleh teman-temannya karena tidak senang perilaku kasus yang sering menyakiti teman-temannya.

Bentuk penanganan perilaku agresif yang bisa diberikan adalah teknik psikodrama. Melalui teknik psikodrama kedua kasus dilibatkan dalam satu kelompok untuk memerankan suatu situasi nyata yang terjadi dalam kehidupan sehari-hari berkaitan dengan perilaku agresif yang dilakukan oleh kedua kasus.

Berdasarkan hasil penelitian ini, diharapkan kepada beberapa pihak untuk menindak lanjuti sebagai berikut:

Bagi pemerintah, sebaiknya memberikan himbauan kepada seluruh stasiun TV untuk tidak menayangkan film-film yang beradegan kekerasan dan sekaligus menghentikan pengedaran $\mathrm{CD}$ atau video game yang beradegan kekerasan. karena film dan game yang beradegan kekerasan dapat menjadi salah satu pemicu bagi anak dalam melakukan perilaku agresif.

Bagi kepala sekolah, sebaiknya memberikan arahan kepada segenap guru yang ada dalam satu instansi naungan kerja, agar selalu melakukan pengawasan terhadap siswasiswi yang memiliki perilaku yang mengarah pada perilaku agresif agar dapat diatasi sejak dini sebelum mengarah pada kecenderungan berperilaku agresif.

Bagi konselor, penting untuk memperhatikan bentuk-bentuk perilaku agresif yang dilakukan oleh siswa-siswi di sekolah dan mengatahui secara mendalam faktor-faktor yang mempengaruhinya agar dapat memberikan pelayanan yang tepat kepada siswa-siswi yang berperilaku agresif, baik malalui pendekatan konseling seperti teknik relaksasi maupun melalui pendekatan bimbingan kelompok seperti pemberian informasi dan teknik psikodrama, sehingga pada akhirnya siswa-siswi di sekolah mampu mengatasi sendiri perilaku agresif yang dilakukan agar tidak menimbulkan dampak terhadap prestasi belajar dan hubungan dengan teman sebaya.

Bagi orangtua, sebaiknya dalam memberikan perlakuan kepada anak, mulai dari kecil sampai dewasa harus memperhatikan dampak positif dan negatif bagi anak yang bersangkutan, karena perilaku agresif yang terjadi dikalangan remaja disebabkan oleh pengalaman masa kecil, perlakuan buruk orangtua, pendisiplinan yang keliru, ketidakjelasan hukuman yang diberikan orangtua terhadap anaknya sehingga menghantarkan anak-anaknya berperilaku agresif semasa rentang kehidupannya.

Bagi siswa, sebaiknya memiliki pengendalian diri yang baik agar mampu megarahkan diri sendiri dalam mengatasi perilaku yang cenderung dilakukan dan mengarah pada perilaku agresif sehingga hubungan sosial dengan teman sebaya tetap bisa terjalin dengan baik dan tidak mengalami kegagalan dalam akademik.

\section{DAFTAR RUJUKAN}

Anggraeni, D. 2011. Perilaku Agresif. (Online), jilid $1, \quad$ No. 4, (devianggraeni90.wordpress.com/2011/02 /23/artikel-perilaku-agresif/- $65 \mathrm{k} \quad-$ Diakses 19 2012)

Berkowitz, L. 2003. Emotional Behavior (buku kesatu). Terjemahan oleh Hartanti Waro Susiatni. Jakarta : PPM.

Koeswara, E. 1988. Agresi Manusia. Bandung: PT. Erasco.

Kurniadarmi, E. 2005. Perilaku Agresif Pada Anak Usia Sekolah dan Remaja Awal (Penelitian Kualitatif dengan 8 Orang Subjek Penelitian). Tesis. (Tidak 
diterbitkan). Kekhususan Psikologi Perkembangan. Universitas Indonesia.

Malik, M. A. 2005. Konsep Dasar Psikologi Sosial. Makassar: Badan Penerbit UNM.

Moleong, L. J. 1996. Metode Penelitian Kualitatif. Bandung: Remaja Karya Bandung.

Mulyono. D. 2003. Metodologi Penelitian Kualitatif. Bandung: Remaja Rosda Karya.

Prawitasari, J. E. 2011. Psikologi Klinis: Pengantar Terapan Mikro \& Makro. Jakarta: Erlangga.

Semium, Y. 2006. Kesehatan Mental 3. Yogyakarta: Kanisius.

Shank, G. D. 2006. Qualitative Research. Second Edition. Congress Cataloging in Publication Data. Person Education, Inc., Upper Saddle River, New Jersey.Columbus, Ohio.

Thalib, S, B. 2010. Psikologi Pendidikan Berbasis Analisis Empiris Aplikatif. Jakarta: Kencana. 